\title{
Dry matter intake in grazing dairy goats
}

\author{
E. Peinado-Lucena ${ }^{1}$, A.G. Gómez-Castro ${ }^{2}$, M. Sánchez-Rodriguez ${ }^{2}$, \\ C. Mata-Moreno ${ }^{2}$ and V. Domenech-Garcia ${ }^{2}$ \\ 1 Cattle Feed Production Unit, Institute of Zootechnics \\ 2 Department of Animal Production, University of Córdoba, Veterinary Faculty, \\ Medina Azahara 9, 14005 Córdoba, Spain
}

(Received 18 March 1993; accepted 18 May 1993)

\begin{abstract}
The contribution of three strata of pasture (grass, woody species and acorns) to the diet of goats during a grazing season was studied. Results showed that in autumn-winter acorns $(61.6 \%)$ were the dominant dietary dry-matter component, followed by woody species $(25.8 \%)$ and grass $(12.6 \%)$. The opposite was true in spring when the greatest contribution was from grass $(61.1 \%)$, followed by woody species $(37 \%)$ and acorns providing a mere $1.9 \%$. In summer, however, woody species increased their contribution to $47.4 \%$, thus constituting an important intake component for grazing goats in the region. Acorns proved to be an important resource, as they are produced at a time when there is a shortage of grass and when woody species have limited nutritional value. Results showed that goats should not be classed solely as browsers but placed midway between strictly herbivorous animals and true browsers, given the contribution of grass to their diet, although an opportunist capacity for adaptation to changes in the quality of available feeds should also be taken into account.
\end{abstract}

KEY WORDS: pasture, caprine, shrubs, trees, intake, grazing

\section{INTRODUCTION}

Accurate measurement of intake is essential for correct evaluation of the contribution of each pasture type to the diet of grazing animals. Most authors believe that intake is governed by the physical and chemical properties of the fodder, which in turn determine retention time in the reticulum-rumen (Thornton and Minson, 1973; Minson, 1971; Allison, 1985). This in valid for overall daily intake, when herds graze heterogeneous areas. However, in the case of isolated species of plants or groups of related species of plants, intake does not depend on the characteristics of the overall diet, and the actual degree to which a species or group of plant species is used will be determined by its palatability, as indicated by selectivity (number of bites taken of this species) and bite size (intake 
of dry matter per bite). Bite size may be a result of the chemical and physical nature of the plant, but will more often be a function of its morphological and structural characteristics (Meuret et al., 1985).

The present study was designed to measure the dry matter intake (DMI) of goats at pasture in Mediterrancan wooded areas, where in addition to grass there were also shrubs and trees, especially Quercus.

\section{MATERIAL AND METHODS}

A study was made of a herd of 220 Florida dairy goats on a semi-extensive system, with seasonal feed supplements where necessary.

The experiment was carried out in the Sierra Norte of Seville, on a mixed holm oak/cork oak range. Vegetation was characteristic of Mediterranean woodland: herbaceous species forming a dense carpet rich in grasses and leguminous species, mainly in spring, with areas of woody vegetation (shrubs and trees, and their corresponding fruit), especially Quercus. Woody species included Cistus albidus L., C. ladanifer L., C. salvifolius L., Pistacia lentiscus L., P. terebinthus L., Quercus rotundifolia Lam., $Q$. suber L. and Olea europaea L.

Following the technique described by Meuret et al. (1985), six representative animals in the flock were selected for observation. The characteristics of the Florida breed, the description of the area where the experiment took place, methodology and management have all been thoroughly described in other studies (Sánchez-Rodríguez et al., 1993; Peinado-Lucena et al., 1992).

Dry matter was obtained according to the method described by Becker (1961). Dry matter consumed was determined on the basis of the number of bites (Sánchez-Rodriguez et al., 1993) and the weight of dry matter per bite (Peinado-Lucena et al., 1992).

Analysis of variance of results was calculated at the Institute of Zootecnics Computing Centre.

TABLE 1

Seasonal variation in daily dry matter intake (g/goat) and percentage contribution of different pasture strata

\begin{tabular}{|c|c|c|c|c|c|c|}
\hline \multirow{2}{*}{ Period } & \multicolumn{2}{|l|}{ Grass } & \multicolumn{2}{|l|}{ Woody sp. } & \multicolumn{2}{|l|}{ Acorns } \\
\hline & DMI & $\%$ & DMI & $\%$ & DMI & $\&$ \\
\hline Autumn-winter & ${ }^{\mathrm{a}} 150.6 \pm 17.3^{\mathrm{a}}$ & 5.9 & $309.2 \pm 53.2^{a}$ & 15.4 & ${ }^{\mathrm{a}} 738.2 \pm 92.6^{\mathrm{b}}$ & 93.7 \\
\hline Spring & ${ }^{\mathrm{b}} 1607.2 \pm 210.6^{\mathrm{a}}$ & 62.7 & $\mathrm{~b}_{974.8} \pm 151.3^{\mathrm{b}}$ & 48.4 & ${ }^{b} 49.3 \pm 14.5^{c}$ & 6.3 \\
\hline Summer & ${ }^{c} 806.4 \pm 198.8^{a}$ & 31.4 & ${ }^{\mathrm{ab}} 728.2 \pm 148.4^{\mathrm{a}}$ & 36.2 & - & - \\
\hline Mean & $854.7 \pm 137.7^{\mathrm{a}}$ & 47.8 & $670.7 \pm 84.6^{\mathrm{a}}$ & 37.5 & $262.5 \pm 64.5^{b}$ & 14.7 \\
\hline
\end{tabular}

Exponents to the right denote strata and the left seasons. Different exponents between strata and seasons indicate statistical significance at least $P \leqslant 0.01$ 


\section{RESULTS AND DISCUSSION}

Statisical analysis of results (Table 1) showed grass consumption was significantly different $(P \leqslant 0.01)$ in all seasons (autumn-winter, spring and summer), whereas woody species and acorns only showed differences between autumn-winter and spring $(P \leqslant 0.01)$. Comparison of the three strata (grass, woody species and acorns) consumed in autumn-winter showed no significant differences between grass and woody species, whereas there was a difference when they were compared with acorns. In spring, all three strata were differently grazed $(P \leqslant 0.01)$; in summer, however, consumption was completely random.

GRASS

Although grass was highly selected in autumn-winter (Sánchez Rodriguez et al., 1993), small bite size, due to grass still being in the early stages of growth (Peinado-Lucena et al., 1992), meant low DMI: 85-293 g/day, or 4.7-16.2\% of total intake. Though a little lower, these results corresponded to those reported by Bourbouze (1980) for goats in a Moroccan Mediterranean ecosystem. Autumn-winter grass contributed a mean of $150.6 \mathrm{~g}$ daily DMI, or $5.9 \%$ of total grass consumption over the grazing season (Table 1). When viewed alongside the autumn-winter contribution of the other two strata (woody species and acorns), grass accounted for $12.6 \%$ of the total (Table 2), while woody species contributed $25.8 \%$ and acorns $61.6 \%$, thus the contribution of grass to total grazing intake was the lowest.

The arrival of spring in late February meant renewed grass growth until the onset of summer in mid-May, and grass intake rose to over $2500 \mathrm{~g} \mathrm{DM} /$ goat/day, the result of increased preference and larger bites due to easy availability. Mean daily grass intake was now $1607.2 \mathrm{~g} \mathrm{DM} /$ goat, or $62.7 \%$ of the daily diet when taken over the grazing season (Table 1). In spring, grass consumption accounted for $61.1 \%$ of total intake (Table 2), higher than that of woody species $(37.0 \%$ ) and acorns $(1.9 \%)$. These proportions have also been reported by Tieszen et al. (1979), Malechek and Provenza (1983), Morand-Fehr et al. (1983), Pfister and Malechek (1986b). More specifically, Bourbouze (1980) reported April grass consumption to be $72 \%$ of intake, while the present study gives an approximate figure of $80 \%$ for the same month. Rosenberger and Meuret (1985) also noted a preponderance of grass in the spring diet (over 50\%), although their figure is lower than in this study. From mid-May onwards, grass became mature, losing its succulence and with it, its palatability; as a result of this the number of bites diminshed and, from June onwards, bite size also decreased with a consequential gradual reduction in intake $(2000 \mathrm{~g}$ at the start of summer down to $100 \mathrm{~g}$ in mid-August). Mean summer grass intake/goat/day was $806.4 \mathrm{~g}$, or $31.4 \%$ of the 
TABLE 2

Seasonal distribution of percentage contribution to diet of each pasture stratum, showing dry matter consumption (g/goat) for each season

\begin{tabular}{|c|c|c|c|c|c|c|c|c|}
\hline \multirow{2}{*}{ Period } & \multicolumn{2}{|c|}{ Grass } & \multicolumn{2}{|c|}{ Woody sp. } & \multicolumn{2}{|c|}{ Acorns } & \multicolumn{2}{|c|}{ Total } \\
\hline & DMI & $\%$ & DMl & $\%$ & DMl & $\%$ & DMI & $\%$ \\
\hline Autumn-winter & 1807.1 & 12.6 & 3710.6 & 25.8 & 8858.2 & 61.6 & 14375.9 & 22.3 \\
\hline Spring & 19286.5 & 61.1 & 11697.4 & 37.0 & 592.0 & 1.9 & 31575.9 & 49.1 \\
\hline Summer & 9677.2 & 52.6 & 8737.6 & 47.4 & 一 & & 18414.8 & 28.6 \\
\hline Total & 30770.8 & 47.8 & 24145.6 & 37.5 & 9450.2 & 14.7 & & \\
\hline
\end{tabular}

total (Tables 1), a figure higher than reported by Bourbouze (1980), (24.2\% in May, compared to $65 \%$ in this study). Grass accounted for $52.6 \%$ of DM intake in summer (Table 2), and was the predominant dietary component. Rosenberger and Meuret (1985) and Meuret et al. (1985) report lower figures for grass, at less than $25 \%$ of DMI. Mean daily grass intake was $845.7 \mathrm{~g}$ of DM or $47.8 \%$ of total annual intake (Table 1), on a par with figures of Wilson and Mulham (1980), Bryant et al. (1979, 1980), Pfister and Malechek (1986a).

\section{TREES AND BUSHES}

When viewed overall, woody species provided $37.5 \%$ of mean daily intake over the year, or a daily quantity of $670.7 \mathrm{~g}$ (Table 1 ), similar to the findings of Bryant et al. (1979, 1980), Campbell and Johnson (1983), Pfister and Malechek (1986a). Other authors (Wilson, 1957; Swain, 1982) deem the contribution of trees and bushes more important. There was a marked difference in contributions between winter and summer. In autumn-winter the consumption of woody species was $309 \mathrm{~g} \mathrm{DM} /$ day, corresponding to $15.4 \%$ of the annual total intake of these species (Table 1), being $25.8 \%$ of overall winter intake (Table 2), double that of grass. As winter changed to spring and shoots began to appear on bushes, especially those of greater palatability, consumption of woody species increased, rising to $974.8 \mathrm{~g} /$ day and accounting for $48.4 \%$ of annual consumption of woody species (Table 1) or $37.0 \%$ of total DMI in spring (Table 2). In summer, when feed intake decreased, woody species accounted for a greater proportion of the diet $(47.4 \%$; Table 2$)$, although the actual quantity ingested was less than that in spring ( $728 \mathrm{~g} \mathrm{DM} / \mathrm{day}$, or $36.2 \%$ of annual consumption of woody species; Table 1). Results reported by Bourbouze (1980) for consumption of bushes in similar areas do not always agree with the results of this study. His results for January and April are somewhat higher, and for May even more so ( $75 \%$ compared to $30 \%$ ), while for July they are low (3.6\%) compared to this study $(49.9 \%)$. In summer, bushes and trees made their greatest contribution to 
the diet, and this agrees with Morand-Fehr (1982), Meuret et al. (1985) and Rosenberger and Meuret (1985) for similar regions.

\section{ACORNS}

Holm oak and cork oak acorns constituted the most important part of the diet in autumn-winter, reaching $1200 \mathrm{~g}$ in some cases, which was over $75 \%$ of the diet. This was in contrast to decreased preference, as noted in bite count, and is explained by the fact that the complete acorn is ingested and that it has a relatively high weight. The absolute and percentage contribution of acorns to the diet decreased from the start of December to the beginning of January, at which point their consumption returned to initial levels and then, as sources were used up, disappeared from the diet. This process coincided with the ripening, fall and exhaustion of acorns, first from the holm oak and then from the cork oak. The consumption of acorns was purely seasonal since, of the entire contribution made by acorns $(9450.2 \mathrm{~g}$; Table 2), $93.7 \%$ (Table 1) was consumed in autumn-winter (738.2 g DM; Table 1), representing $61.6 \%$ of the total intake for that season (Table 2), while the remaining $6.3 \%$ (Table 1) was eaten in spring (49.3 $\mathrm{g} \mathrm{DM}$, Table 1), this latter figure only accounting for roughly $(1.9 \%)$ of fodder intake for that period (Table 2). Acorns were so important that the accounted for $14.7 \%$ (Table 2) of mean daily intake when viewed over the entire year (262.5 g dry matter; Table 1).

Studies on the consumption of acorns by goats are extremely scarce. Bourbouze (1980) reported figures of $25 \%$ of intake in October and $69 \%$ in January, when availability is high. The latter figure coincides almost exactly with that of the present study for January $(71 \%)$. In any case, the importance of the contribution of acorns to the diet cannot be understated, given that they are produced in a period when grass intake is strictly limited due to its scarcity, and when the nutritional value of woody species is low.

The results show that of the total DM available in pasture during the grazing year almost half corresponded to spring and the other half was split between autumn-winter and summer. Grass made an important contribution to the diet of goats, as also did woody species, and although the role of acorns was more circumstantial, they still made an important contribution to the annual total.

\section{REFERENCES}

Allisonn D.C., 1985. Factors affecting forage intake by range ruminants: A review. J. Range Manage. $38,305-311$

Beker M., 1961. Análisis y valoración de piensos y forrajes. Ed. Acribia. Zaragoza. Spain, pp. 255 
Bourbouze A., 1980. Utilisation d'un parcours forestier pâture par les caprins. Fourrages 82, $121-144$

Bryant F.C., Kothmann M.M., Merrill, L.B., 1979. Diets of sheep, Angora goats, Spanish goats and White-tailed deer under excellent range conditions. J. Range Manage. 32, 412-417

Bryant F.C., Kothmann M.M., Merrill L.B., 1980. Nutritive content of sheep, goat and White-tailed deer diets on excellent condition rangelands in Texas. J. Range Manage. 33, 410-414

Campbell E.G., Johnson R.L., 1983. Food habits of Mountain goats., Mule deer, and cattle on Chopaka Mountain, Washington, 1977-80. J. Range Manage. 36, 488-491

Malechek J.C., Provenza F.D., 1983. Feeding behaviour and nutrition of goats on rangelands. World Anim. Rev. 47, 38-47

Meuret M., Bartiaux-Hill N., Bourbouze A., 1985. Evaluation de la consomation d'un troupeau de chèvres laitiéres sur parcours forestier. - Méthode d'observation directe des coups de dents. - Méthode du marqueur oxyde de chrome. Ann. Zootech. 34, 159- 180

Minson D.J., 1971. The digestibility and voluntary intake of six varieties of Panicum. Aust. exp. Agr. Anim. Husb. 11, 18-25

Morand-Fehr P., 1982. Sistemas de producción de leche de cabra en los paises de la cuenca mediterránea. XIV Jornadas de estudio. Economia y técnica de la producción de leche y queso de oveja y cabra. I.T.E.A. n. 1

Morend-Fehr P., Bourbouze A., Le Houerou H.N., Gall C., Boyazoglu J.G., 1983. The role of goats in the Mediterranean area. Livest. Prod. Sci. 10, 569-587

Peinado-Lucena E., Sanchéz-Rodriguez M., Gomez-Castro A.G., Mata-Moreno C., Gallego-Barrerd J.A., 1992. Analysis of dry matter intake per mouthful of a herd of grazing dairy goats. Small Ruminant Res. 7, 215-223

Pfister J.A., Malechek J.C., 1986a. The voluntary forage intake and nutrition of goats and sheep in the semi-arid tropics of northeastern Brazil. J. Anim. Sci. 63, 1078-1086

Pfister J.A., Malechek J.C., 1986b. Dietary selection by goats and sheep in a deciduous woodland of northeastern Brazil. J. Range Manage. 39, 24-28

Rosenberger S., Meuret M., 1985. Un histoire de coups de dents. La Chèvre 151, 21-27

Sánchez-Rodriguez M., Gómez-Castro A.G., Peinado-Lucena E., Mata-Moreno C., Domenech-Garcia V., 1993. Seasonal variation in the selective behaviour of dairy goats on sierra areas of Spain. J. Anim. Feed Sci. 2, 43-49

Swain N., 1982. Note on the grazing behaviour of sheep and goat on natural degraded semi-arid range land. Indian J. Anim. Sci. 52, 829-830

Thornton R.F., Minson D.J., 1973. The relationship between apparent retention time in the rumen, voluntary intake, and apparent digestibility of legume and grass in the sheep. Aust. J. Agr. Res. $24,889-898$

Tieszen L.L., Hein D., Qvovtrup S.A., Troughton J.H., Imbamba S.K. 1979. Use of d13 C values to determine vegetation selectivity in East African herbivores. Oecologia (Berlin) 37, 351-359

Wilson P.H., 1957. Studies of the browsing and reproductive behaviour of the East African dwarf goat. E. Afr. Agric. J. 23, 138-147

Wilson A.D., Mulham W.E., 1980. Vegetation changes and animal productivity under sheep and goat grazing on an arid Beiah (Casuarina cristata)-Rosewod (Heterodendrum oleifolium) Woodland in Western New South Wales. Aust. Range J. 2, 183-188

\section{STRESZCZENIE}

\section{Pobieranie suchej masy przez pasące się dojne kozy}

Badano proporcje trzech skladowych pastwiska (trawa, gatunki drzewiaste i żołędzie) w dawce pobieranej przez kozy w sezonie wypasowym. Wykazano, że w okresie 
jesienno-zimowym żołędzie były dominującym składnikiem pobieranej paszy $(61,6 \%)$, następnie pasze drzewiaste $(25,8 \%)$ i trawa $(12,6 \%)$. W sezonie wiosennym udział traw był największy $(61,1 \%$ ), gatunki drzewiaste stanowiły $37,0 \%$, a żołędzie nie więcej niż $1,9 \%$. W sezonie letnim udzial pasz drzewiastych zwiększył się do $47,4 \%$, stanowiąc znaczącą część paszy pobieranej przez kozy w tym rejonie. Żołędzie miały istotne znaczenie jako źródło paszy, dostępne były bowiem wówczas, gdy na pastwisku było niewiele trawy, a dostępne pasze drzewiaste miały niewielką wartość pokarmową. Wyniki te pokazują, że kozy nie powinny być zaliczane do zwierząt skubiących pasze, ale powinny być umieszczone pomiędzy całkowicie trawożernymi a skubiącymi, przy znacznym udziale traw w dawce. Przystosowanie się zwierząt do zmian jakości dostępnych pasz winno być także brane pod uwagę. 